2016-12-09

\title{
Making Policy in the Classroom
}

\author{
Hohmann, Ulrike
}

http://hdl.handle.net/10026.1/8115

$10.1177 / 1745499916679561$

Research in Comparative \& International Education

SAGE Publications

All content in PEARL is protected by copyright law. Author manuscripts are made available in accordance with publisher policies. Please cite only the published version using the details provided on the item record or document. In the absence of an open licence (e.g. Creative Commons), permissions for further reuse of content should be sought from the publisher or author. 


\title{
The final, definitive version of this paper has been published in Research in Comparative \& International Education 11 (4) 380-393, December 2016 by SAGE Publications Ltd, All rights reserved. ( ) Ulrike Hohmann
}

\section{Making policy in the classroom}

\author{
Ulrike Hohmann \\ Plymouth Institute of Education, Plymouth University
}

\section{Abstract}

The concept of street-level bureaucracy (Lipsky 1980; 2010) examines the form and extent discretion takes in teachers' and other public policy enactors' work and how they negotiate their way through sometimes contradictory policy imperatives. It provides a framework for straddling top-down and bottom-up perspectives on policy making. In this article I argue that comparative education research should take advantage of the analytical framework this perspective offers. It requires, firstly, mapping out policies resulting in the characteristics of teachers' discretion in a particular national or local context and, secondly, to observe how teachers make use of this discretionary space in their daily work. Lipsky has shown strategies employed by street-level bureaucrats to alleviate workload pressures and how they make policy in this way. Applying street-level bureaucracy in comparative education research illuminates why straight forward policy transfer is problematic and how it can be employed to explore practices around inclusion and exclusion.

\section{Keywords:}

Street-level bureaucracy, comparative research, education policy, England, Germany

\section{Introduction}

Education is increasingly treated as a global commodity which can be imported and exported in order to achieve desired outcomes of attainment. The decision about the direction of policy transfer is usually driven by the results of large-scale international surveys. There are a number of problems with comparison at mainly nation state level and making top-down policy decisions based on it. As an alternative approach to this form of comparative research I will introduce Michael Lipsky's (1980; 2010) theory of street-level bureaucracy as a useful tool in comparative education. The strength of a focus on street-level bureaucrats and their discretionary power is that it provides a framework for straddling top-down and bottom-up perspectives on policy making.

In the high-speed world of politics, policy formation and implementation, large-scale comparisons and rankings of educational outcomes, like the OECD flagship Programme of International Student Assessment (PISA) or TIMSS (Trends in International Mathematics and Science Study), can lead to policy epidemics (Levin, 1998; Phillips \& Ochs, 2004). The temptation is great to 'borrow' policies that apparently work, indicated by the position of a country in the consulted league table. Global 'policy speak' as an outcome of and motivation for policy importing and exporting (Ball, 2013) can be read as evidence of convergence in education. However, a closer look reveals that at times it is just 
the name of a policy but not the content that has been borrowed and that the policy in transit is mediated by the national and local context including other policies which may not be directly linked to education. The form policy import takes is influenced by the general approach to public policy, the understanding how policy is made and the nature of the links between aims, policy formulation, implementation and desired outcomes (Hupe, Hill \& Nangia, 2014).

Top-down approaches in policy analysis are interested in whether stated policy aims lead via policy formulation and implementation to the desired outcomes and if this is not the case explore what interferes in this compliance model of policy (see Hill, 2009b, for an overview). Here discretion can be interpreted as dangerous opportunities for practitioners to follow their own, personal goals. The contrasting bottom-up alternative is less constrained by the assumptions about the process itself but focuses on possible actions and choices at the site of the problem (Elmore, 1980). Lipsky's (1980; 2010) work includes both the top-down and bottom-up perspectives and with that highlights the nature of policy as it is made at the 'coal face'. The focus on discretion demands attention to the rules or policies within which the discretion of workers in public services is invited or taken into account. Apart from the inevitability of discretion in human encounters the employment of discretion on parts of the street-level bureaucrat may influence the meaningfulness of the service in the eyes of the client (Tummers \& Bekkers, 2014) and in this way shapes socio-cultural perceptions of public policy.

\section{Street-level bureaucracy}

Michael Lipsky's (1980) perspective of street-level bureaucracy highlights the importance of discretion across occupations which encounter citizens in their role as public service workers. Streetlevel bureaucrats work in a context of ambiguous or vague goals with an abundance of rules which are at times contradictory and allow more than one way of action or inaction (Lipsky, 1980; Lipsky, 2010; Maynard-Moody \& Musheno, 2003). Discretion acts as a lubricant in the complex public policy machine (Evans, 2011). Street-level bureaucrats do have considerable discretion because their work entails making decisions about their clients where the individual requirements only emerge during the contact with the client and may therefore be negotiated and because the consequent decisions do affect these people's life chances (Lipsky, 1980; Lipsky, 2010).

Demand for public services tends to increase and, even when service levels are extended, eventually demand exceeds supply in quantitative or qualitative terms, or both. The implication is that streetlevel bureaucrats perform their work with limited or even inadequate resources (Lipsky, 1980). Specific services do target particular clients, but it is during the encounter that street-level bureaucrats make decisions whether they are dealing with a deserving client. Maynard-Moody and Musheno (2003) emphasise that this is the initial instance of a discretionary power street-level bureaucrats possess. As the relationship between street-level bureaucrat and client unfolds, the question of worthiness will be revisited and used to establish the street-level bureaucrat's power.

Street-level bureaucrats are presented with the dilemma arising from the paradox of treating all citizens alike but being responsive to individual cases. Professionals like teachers, social workers, police officers 'interact with citizens in the course of the job and have discretion in exercising authority; in addition, they cannot do the job according to ideal conceptions of the practice because of the limitations of the work structure' (Lipsky, 2010, : xvii). Under certain circumstances these 
professionals working with people develop particular strategies to cope with pressure and narrow the gap between their ideal of their role and what they feel able to provide. These strategies include limiting demand, e.g. by routines, better utilization of resources and availability, modifying the concepts of the job and modifying the concept of the client. Initially Lipsky (1980) had used the term street-level bureaucrats for those whose professional traditions and locally established work practices had emerged from strategies addressing the dilemma arising from interdeterminacy, little control, limited resources and the potential of expanding workload. The concept of street-level bureaucrat was received and at times misrepresented as meaning all teachers, police officers, social workers and so on in public services as pointing to their misery and overload (Lipsky, 2010). Nevertheless, many of these workers are to some extent happy with their work and like what they do.

Street-level bureaucracy has been adopted by a number of researchers to explore the strategies as taken by particular professional groups in particular circumstances, covering a wide range of areas of public policy (see overviews in Brodkin, 2012; Hupe, 2013; Rønning, 2011; Rowe, 2012) and allows an exploration of 'change in organisational practice, discretion of frontline workers and complex decision making in the context of formal policy ambiguity and uncertainty' (Brodkin, 2003, p. 151). A focus on one kind of street-level bureaucrat in a range of settings can throw light on distinct forms of discretion rooted in micro-cultures of frontline practice (Ellis, 2011). In this case these street-level bureaucrats are positioned in a particular set of policy intentions and policy texts at the top level. A focus on discretion in comparative work opens up the potential to relate the behaviour, experiences and habitus of a particular professional group with the policy framework within which they operate. The bottom-up element in this approach allows including a broader range of policies than a topdown perspective and is better suited to include socio-cultural conditions and therefore more likely to avoid ethnocentric pitfalls ripe in comparative research.

Empirical studies on street-level bureaucrats produced attempts to conceptualise the slippery term 'discretion'. Discretion is neither good nor bad, but can have beneficial or negative effects for clients, street-level bureaucrats themselves and their organisation. It cannot be assumed that discretion is the requirement to negotiate a decision within or against established rules and conditions but may be the actions taken due to the lack of knowledge of regulating policies (Dorch, 2009) or even of a policy framework that does not exist (Berkman \& Plutzer, 2010). Smith (1981 in Hupe, 2013) differentiates between de jure discretion, or the authority to act and de facto discretion, or the power to act, though not necessarily according to the established rules. Another way to conceptualise discretion in relation to rules is to typify discretion as within the rule, discretion among the rules, discretion beyond the rules and discretion against rules (Barberis \& Buchowicz, 2015). This distinction offers a useful framework for research within one particular policy framework or for case study research drawing on cases from different nation states. Alternative ways of conceptualising discretion offer more readily tools for comparative analysis. Much research is concerned about the squeeze of street-level bureaucrat's discretion. The theorization of distinct though interrelated forms of rule discretion, value discretion and task discretion showed that new public management reduced school teachers' and social workers' rule making capacity (Taylor \& Kelly, 2006). Tummers and Bekkers (2014) differentiate street-level bureaucrats' discretionary decision according to the relationship with the client. They may be moving towards the client, moving away from the client or turn against the client. Discretion can be examined as an 
independent variable, as a condition to examine outcomes for clients or as dependent variable, as taken by professionals in a particular set of conditions (Hupe, 2013).

The examination of strategies developed by teachers as street-level bureaucrats in order to cope with their particular workload allows us to explore and compare the links between policy on various levels and outcomes. These strategies may be observed as they are established, as a response to increased pressures or they may be seen as consolidated in particular practices as a professional habitus in a particular point in time and a specific context. When this analysis is extended to include cross-national data it provides a framework for comparative work. In the following section I will set out the context within which teachers can be conceptualised as street-level bureaucrats followed by a discussion of the strategies used by street-level bureaucrats with particular references to teachers. To demonstrate the potential of street-level bureaucracy as a perspective in comparative education research I discuss some insights gained from Lipsky's writing when I explored data as part of the CATE project (Comparing and Analysing Teaching in Northern Europe), observing a range of native language and mathematics lessons in English and German secondary schools and interviewing teachers (Kelly et al., 2014; Kelly et al., 2013a; Kelly et al., 2013b). The section and subsections of the paper 'making policy in the classroom' are based on the data I generated for this project. The data are two full, audio recorded lesson observations, each followed up with an interview per teacher. My sample comprised two teachers in England and four teachers in Germany. My critical exploration was strengthened by the collaborate analysis of all data sets of this project and extensive working discussions with the academics in the project team.

\section{The schooling of children}

The education of children and young people is a central feature of any modern state, usually expressed by compulsory and free basic education, and is called upon to fulfil a number of purposes, many of which come under the umbrella of welfare state provision. Schools offer routes to qualifications and, connected to this allocate and/or select individuals for future roles. They are the place of socialisation additional to the family, aiming to support social integration and support the acquisition of cultural knowledge and practices. At the structural level aims range from ensuring economic growth and competitiveness to offering a lever to promote a just society. The social purpose education encompasses is in empowering young people and allowing them to be active citizens now and in the future. From a political and cultural perspective education is presented as the key to regaining a role in the globalised world for nation states and individuals and it has taken recently on board the Promotion of citizenship and the common values of freedom, tolerance and non-discrimination (European Commission, EACEA \& Eurydice, 2016). In addition, schools have custodial tasks (Flechsig \& Haller, 1975), are administrative institutions (see Fend, 1981; Fend, 2008; Herzog, 2011) and can provide other services, like (free) school meals and access to medical services to almost all children of a generation (Hill, 2009a). The prominence each of the purposes takes and how they translate into practice varies between countries, locations and individual schools.

Governments can take on the role of direct providers of schools, funders and regulators of education. Education policy aims to determine how education is funded and the structure of the system including its control, who is allowed to teach and the qualification of teachers, teachers' working conditions, including payment of teachers, subsidies for students and/or their families and, of course, it makes demands on the content of teaching and assessment of pupils. Governments are involved in 
providing and/or regulating services provided by school not directly related to education, like after school care, sport and drama clubs and pastoral care. Teachers and schools may be charged with responsibility for child protection by the government.

\section{From public policy into the classroom}

Policy objectives as such are not very useful for understanding what happens in the classroom (Dorf et al., 2013; Hill, 2009b). Education is severely influenced at the point of delivery, because it cannot be separated from its cultural context (Alexander, 2008) and because of the abundance of purposes of education. By the same token it is difficult to read current policy aims into observed practice. These difficulties of identifying a tight and easily observable fit between policy and practice invite one to explore the policy practice relationship from a different angle. The classroom is the heart of education where activities take place aiming to 'transform' children via learning as a necessary process of developing knowledgeable, responsible and autonomous adults.

\section{Teachers in the classroom}

Bernstein's (1996) pedagogic device offers a useful and elaborate theory and analytical tool to link politics and policy with teachers' behaviour and pupils' attainment and the various selection processes and transformation of knowledge. Teachers are at the receiving end of the struggles within and between the official recontextualising field or the education policy arena and the pedagogical recontextualising field, the experts of teaching and learning, which translate knowledge into school knowledge and practices of teaching. Depending on their ability to gain access to the various debates around these education issues, and their willingness to engage with their details, they can consciously participate, for example by responding to calls of consultations, political activity or their own academic research, and are by default further interpreters of the struggle. The teacher is the vital link between these recontextualizing fields and the reproductive field, the school, or in other words, teachers are the key connection between policy and practice through further transformation of knowledge in classrooms by teachers and students together. This role of teachers has been described in a number of ways. Croll (1996) calls them the ultimate implementers of education policy. 'Policy enactment' captures better the complex process of negotiation and contestation and the interplay of interpretation and translation. Some of this research concentrates on mid-level managers of schools (Spillane et al., 2002), other mid-level policy actors (Singh, Thomas \& Harris, 2013) or examines how policy actors account for enactment and meaning making (Ball, Maguire \& Braun, 2012; Braun, Maguire \& Ball, 2010). Yet it is in the classroom where policy is made (Lipsky, 1980; Lipsky, 2010) and actualised (Maynard-Moody \& Musheno, 2003).

\section{Teachers as street-level bureaucrats}

Teachers like other street-level bureaucrats work with the public and in this role represent the frontlines of government policy. Objectives for schooling are related to the variety of purposes of education, a number of other anticipated outcomes (see above) and are further influenced by existing stakeholders. For each of the goals there are a number of rules that apply, some binding, some negotiable and some discretionary. Rules exist in the form of acts, directives, expectations of professional bodies, institutional rules or agreements between individual teachers, parents and pupils, to name but a few. Some of these are visible and public. Others are embodied in teachers' practices, related to institutional structures and develop in the context of discourse of effective teaching. 
Teachers have in common with other street-level bureaucrats that their clients are non-voluntaryat least as long as we define the pupils as clients. A twist for the application of Lipsky's theory is that teachers work most of the time with a group of pupil clients, so their professional relationship with pupil clients is witnessed by others clients. The potential shift of power towards clients, the greater visibility of discretionary decisions by teachers may be offset by children's weaker position in society and being perceived as victim, threat or investment (Hendrick, 1994). Maynard-Moody and Musheno (2003) highlight that the decision about the person and whether he or she qualifies as a client precedes policy enactment. Children may have the right to be educated and may be required to attend school, though they may be excluded from educational settings, for short periods having to leave the classroom or indefinitely being excluded from a particular school or a particular type of school. The basis for exclusion is the unworthiness of the pupil, due to particular behaviours in relation to themselves, other people and or academic achievement. Decisions that are mainly value discretion can be disguised as following rules within elements of rule discretion. When there is uncertainty whether the parents are the clients or customers, especially in a quasi-market or private system of education, the analysis gains complexity.

Street-level bureaucrats perform their work with limited or even inadequate resources (Lipsky, 1980; Lipsky, 2010; Maynard-Moody \& Musheno, 2003). Education, like other public services draws on ideas of social justice and equity, protection of citizens and supports the functioning of society. This is the backdrop against which demand always will exceed provided services. For example, the demand for longer compulsory schooling, extended school days, a broader range of subjects covered or smaller classes could easily outstrip available resources. These demands can be triggered by international comparisons. For example, in the aftermath of the PISA shock in Germany, smaller classes, lowering of the compulsory school age, extension of teaching time, more German lessons etc. were called for (Klieme et al., 2010; Verbeet \& Weinzierl, 2011). On one level, in contrast to other street-level bureaucracy, teaching is fairly predictable at least concerning the number of children requiring schooling. However, preferences for particular school types and parents ability to choose schools, the introduction of quasi-markets, perceptions and reactions to special educational needs, a shift of emphasis within the many goals of education or the recent demand of serving the interest of economic competitiveness (Ball, 2013) lead to reforms of the established system and a new allocation of resources. Observing teachers at work show that there are always exceeding demands on teachers' attention, expertise and time, despite strategies to efficiently use resources, like various forms of whole class teaching, peer teaching, and flipped classroom.

Street-level bureaucrats enter their profession committed to ideal conceptions of their job and what can be achieved. These ideals may have been part of the motivation why the profession was chosen as a career and have been inculcated during training. Consequently, they contribute the basis for value discretion but this may change over time. At the 'coalface' of public policy they encounter the impossibility of fulfilling these aspirations. The reality of their jobs is that they work on segments, have limited control of the outcome of their work, do not control the 'raw material' or even the pace of work and are supposed to fulfil indeterminate objectives (Lipsky, 1980; Lipsky, 2010). Teachers teach particular subjects in particular schools, they can support pupils but not control their attainment, they have to work with children enrolled as pupils, are bound up by the structures of schooling including curricula, term times, hours of teacher pupil contact and work towards changing expectations about outcomes to achieve. Nevertheless, the acceptance of discretion of street-level bureaucrats is important in upholding the belief that these workers hold the key to the well-being of 
their clients. Only a professional judgement on the condition of the client and his or her situation allows an adequate decision on action and/or further professional engagement of a particular kind. In education there is a strong emphasis on the relation between teacher and pupil to promote learning. It requires the knowledge and skills of the professional and refers often to tacit knowledge gained through professional experience. The requirements of being licensed as a teacher usually include placements and assessed work experience.

The dilemma arising from the paradox of treating all citizens alike and, at the same time, to being responsive to individual cases (Lipsky, 1980; Lipsky, 2010) as well as the stickiness of policy pathways lead to contradictory expectations and structures. Teachers who were not able to develop a strong professional identity (often labelled as semi-professions), for example due to the absence of the taught and researched specialism of pedagogy (as in the German Erziehungswissenschaften, the science of education), are in danger of being a fragmented profession and open to 'modernisation' (Beck, 2008). For example, in England the emphasis on individualism in education was well reflected in the 'golden age of teacher control' until the mid-1970s (Whitty, 2001) and encompassed occupational professionalism. The 'discourse of derision' (Ball, 1990) smoothed the way to a tight prescription of what and how to teach, to controls and a discourse of accountability and in this way restricted teachers' professionality (Ward \& Eden, 2009; Whitty, 2001), turning occupational professionalism into organisational professionalism (Evetts, 2009). Nevertheless, the unlimited curriculum before the 1988 Education Reform Act is as much a myth as the inability of teachers to assert their authority after the introduction of the National curriculum in England (McCulloch, Helsby \& Knight, 2000). Despite various means to inculcate a particular version of teaching practice, government documents setting out contemporary understanding of effective education emphasises that children need individual responses appropriate to their learning, (see for example Standards for teachers in England (Training and Development Agency (TDA), 2007) and their revision (Department for Education (DfE), 2011).

For Taylor (2007) recent reforms of the education system in England have eroded the discretionary power of teachers to such an extent that the characterisation of teachers as street-level bureaucrats is not applicable anymore. It should be noted that the respondents in his research differentiate between the loss of autonomy in making rules within the school and the ability to make decisions in the classroom. In other words, there was a stronger squeeze of rule discretion but less curtailment of task discretion. However, the characteristics of public services and the relationality of education result in limits to the standardisation of the teacher pupil encounter. 'Thus, like putty, discretion can be squeezed by oversight and rules, but never eliminated; it will shift and re-emerge in some other form in some other place.' (Maynard-Moody \& Musheno, 2003, p. 10).

\section{Making policy in the classroom}

Policies impacting on teachers' practice may come with a dizzying speed (Ball, 2013) and may introduce tasks not connected to teaching, for example, marketing of the school (Lundström \& Parding, 2011) or connected to the extension of time children spend in all-day schools as in Germany (Autorengruppe Bildungsberichterstattung, 2014). The teachers we observed and interviewed as part of the CATE study showed a range of awareness of current policies regulating their practice in the classroom. Some teachers expressed that their interest in the education policy was rooted in the ability to help promote good practice, for example by taking responsibility for teacher trainees. 
Others explained that only by joining in and taking responsibility for implementing new government initiatives would they have a chance of understanding the translation of policy into practice in a way that was suitable for their school or their personal approach to teaching and learning.

Teachers make policy in the classroom. They work in the context of cultural and social traditions and in a particular policy framework that regulates which children attend which school and by means of inclusion/exclusion teachers make policy at classroom level. Teachers are faced with demands expressed by children and parents, as well as expectations from colleagues and their superiors. How they deal with these will be used as an example of how useful the concept of street-level bureaucrat is for comparative enquiry.

\section{Limit demand by maximising available resources and client compliance}

Lipsky (1980) identified several ways how street-level bureaucrats limit demands of clients by maximising the utilization of available resources, developing routines and simplifications and by obtaining clients' compliance. These strategies are developed within and are influenced by existing structural characteristics. Class-size and composition, contact time and staffing levels are regulated by state or local policy and are the outcome of historical processes. These structures impact on the extent of value discretion available to teachers Teacher training situated in the particular philosophical approach as found in different countries (McLean, 1990) can provide means to teach efficiently large groups of children or expectations to pay attention to the needs of individual children (Alexander, 2000; Luxton \& Last, 1998; Meyer, 2004) and lead to particular preferences.

Education policy in Germany organises school attendance as one or more grades (Klasse) of a one year cohort in which children remain throughout their time in the school and in which they are taught in all subjects. If the number of children in a particular grade falls below a specified level, it may be amalgamated with another grade. Teachers prefer to work with small classes and there are a number of strategies that can be employed to influence numbers. In street-level bureaucracy terms class size in general (children enrolled) and on a daily basis (children present) is the outcome of decisions on the worthiness of clients or which child deserves to be taught in a particular grade by a particular teacher. A system that requires pupils to repeat a year if attainment is too low and in which children can move up or down to other kinds of secondary school invites some manipulation, for example by offering special support to individual students to avoid exit due to low attainment and risk resulting in amalgamation.

Similar strategies by teachers of supporting pupils can be found in systems operating in a quasimarket, as in England, where the survival and resourcing of a school depends on maintaining a particular enrolment level. However, here it is unlikely to reduce workload, not even in the long run.

There is a fear out there from a teaching point of view and certainly from a school leadership point of view, fear of failure and fear of failure means you do almost anything you can to get the results within the rules. Which means we do take bits of course work through with them. We do break our backs to a certain extent. And this is quite a tension within the leadership group as well - we have regular discussions which are around the idea, do we let them fail. We should let them fail probably more than they do. And we go probably too far in terms of helping them out. (Teacher, England) 
The discretion granted to teachers through assessment leads to particular forms of practice. If tests and other pieces of work are set and marked solely by the teacher their ability to influence records of attainment is greater than in a system where tests are set nationally and assessment of these pieces of work are undertaken externally. In a system where low attainment can lead to exclusion from the grade and/or school, frequent tests and other forms of assessment become tools to achieve compliance by pupils. Additionally, a focus on components of summative assessment can reveal further means of compulsion and motivation. Are there certain behaviours that lead to less favourable marks which are not related to the knowledge or skills held by pupils? For example, are students marked down who do not bring a specific notebook, cannot show their homework or show any kind of disruptive behaviour during lessons?

When exclusion from a particular grade does not hold a strong grip on pupils, either because the boundaries around the group of children are weaker due to streaming and teaching in different groups across the year cohort, because the repetition of a year is unusual or comprehensive schools pre-empt movements from one school type to another, other means of achieving pupils compliance are dominant. Particular rules justify punishment and other forms of exclusion. I observed special seating arrangements or special tasks for children that had digressed. In one school a system of regular public monitoring of the behaviour of a pupil was established. Often these possibilities are available to teachers in the form of school rules and our observations showed that teachers in the classroom choose and bent these rules according to their view of tasks and understanding of pupils' needs. Rules around school uniforms, chewing gum and mobile phones presented themselves readily for managing pupil compliance.

\section{Re-dlefining the job}

Another strategy to narrow the gap between the ideal of teaching and the daily experience is to redefine the job. Observed practice in classrooms reveals how the demand by clients, from contentrelated questions to personal matters is controlled, and it also shows teachers' construction of their job. Team teaching may be one way to alleviate work pressure as does making use of a teaching assistant, or excluding children in one form or the other, but it also shows what teachers believe to be their responsibilities. The abundance of goals in combination with teachers 'unsettled occupational identity' in the context of the national discourse of education impacts on the concept of their work teachers apply. The strength of a professional identity and the nature of granted discretion as perceived by teachers' influences whether goal selection is seen as a positive part of practice or a more subversive role of teaching.

There are two areas of day to day work in classrooms which are particularly useful in highlighting the concept of the job of teaching and, connected to it, the concept of the pupil deserving to be taught, important for street-level bureaucrats, as these concepts are embedded and developed in national policies. One area is the use of homework, because it allows exploring the boundaries of teachers' responsibility and the extent to which school systems relate and are linked to the lives of children and their parents. The other area concerns the rules of participation in the form of speaking in the classroom, because it illustrates the relationship between teacher and pupil.

Schools may have homework policies, setting out how much time children are expected to spend on homework, when it is set and parents' involvement. Homework can be set to consolidate what has been learnt during the lesson, prepare the next step or a new topic or involves some practical work 
to prepare teaching and learning materials. Research on whether homework contributes to widening or reducing the gap between high and low achievers and which conditions contribute to one or the other is inconclusive (for example Rønning, 2011; Sharp, Keys \& Benefield, 2001). In Germany the idea of homework is dominant. Stereotypically, reflecting post-war traditions, homework is what German children do at home in the afternoon, amongst other extra-school activities. When parents are not available or able to support their children, alternatives have to be found. Not surprisingly the use of private mentors is prolific in Germany (Schneider, 2005).

Teachers' use of homework showed a wide range of practice. Some teachers set very little homework because they were resigned to the fact that most pupils would not engage with them. In an education system, like Germany, that is based on the assumption that teaching is most successful if taking place in groups of homogeneous children regarding knowledge and skills, practices that contribute to differences in learners is less useful. During the lessons in Germany I attended homework was set as the same task for all children, often found in the used textbook. It was assumed that in this way weaker learners could catch up and practice the application of content. Advantages of using textbook tasks were less time required for preparation, results could be controlled and evaluated as a whole class activity and in this way reduce workload. However, we have observed setting of individually tailored homework, addressing perceived needs of individual pupils. This was more prominent in the English context, linked to the ideal of teaching as tailored engagement with individual pupils. Homework can be used as assessment tasks and can, if feedback is provided, increase the workload of teachers.

An important aspect of the regulatory discourse is how speaking in the classroom is managed. In contrast to other street-level bureaucrats and client relationships, the hierarchical power relationship is underlined by an adult teacher meeting the child pupil, linking what happens in the classroom to the context of social and cultural expectations about the relationship between generations. Pupils are expected to raise their hand when they want to speak. This rule is known by everybody and at times used outside the classroom, for example in meetings or, tongue in cheek, during informal conversations to get a word in. Inside the classroom transgressing this rule is the arena for teachers establishing proper client behaviour. In our observations the raising hand rule was often ignored or forgotten by pupils in their enthusiasm to contribute or desire to shift pedagogical discourse in another direction. Teachers used this rule flexibly with the purpose of controlling the amount of contribution by particular students, to build confidence (by inviting weaker pupils to have a go at an easier question) and to reduce the noise level if desired. However, since the rule does not work in reverse teachers can ask for contributions even when a pupil did not raise his or her hand. Here the doors are open to encouragement or to instilling fear. Overall, teachers had established what counts as an acceptable noise level to them and what kinds of conversations between children are permitted. In some of the German classrooms children worked together, without being prompted by the teacher, helped each other out with pens or erasers and some dipped in and out tasks at hand. We observed fewer instructions on how to work than in England.

All teachers have to handle the tension of on the one hand serving all pupils and on the other hand supporting individual children. This has to be solved by finding a balance between the contradictory goals. Solutions depend on the concept of pupil/client developed by teachers. Observations showed that private matters of children were always present in the classroom. I observed conflicts between 
children, heard children talking about family matters that had an impact on their work and children asking questions that were of a private nature. Many teachers emphasised that pupils must have the right to bring aspects of their lives into the classroom. I also observed how teachers showed interest in the particular family situations and pride themselves in making the lesson content relevant by linking it to the everyday experiences of children. Others tried to make a difference between what happens in the classroom during the lesson and what takes place outside the classroom.

I think the personal level is very important. Well, they don't know me as a person, but as a teacher. They do know that as a teacher I have to be sometimes more strict and that I have to say uncomfortable things, which they do not like. However, they know, too, that during break time they can talk to me about anything in inverted commas. I find it very important that they know this. One is business the other one is that I respect you as human being. Like the pupil in the first row. She is really very weak. We often argue in maths because she doesn't do her homework and does not participate. But we still get on well. (Teacher, Germany)

This teacher draws a clear distinction between the concept of the pupil/client and the concept of the child. Interestingly some teachers talked about colleagues who emphasise the teacher-pupil relationship and exclude the adult-child dimension. Consequently they observed less work satisfaction in their colleagues and felt that in this way the ideal of the teacher is somewhat betrayed. Making the distinction between pupil and child softens the harshness of judgment regarding the worthiness of a client and decisions within the national policy framework. A teacher may not be able to support all pupils to attain grades to a high level, but he or she can offer other kinds of support and recognition to all children in their professional care. Here there are important links to the concept of childhood and how adults and social institutions share responsibilities.

\section{Conclusion}

The exploration of education policy by applying Lipsky's (1980; 2010) framework of street-level bureaucracy to comparative research and analysis has shown the potential of this approach. It straddles the top-down and bottom-up perspectives on policy making and avoids some of the pitfalls of each of these. Exploring the practice of teachers in the classroom against the backdrop of policies regulating demand, setting out what the job of teachers is and defining clients (pupils and their parents) in relation to teachers is a useful framework for comparative, cross-national research. Some of these aspects are not new and are addressed when comparing countries. However, a specific focus on the means of the 'squeeze' of discretion, its effects on teachers' ability to make decisions in practice and the patterns emerging in local and national contexts offers a new angle of enquiry. It may reveal particular distinctions between 'authorised' and 'unauthorised' discretion or between compliance and subversion (Brodkin, 2011) exerted by teachers, whether expressed in the policy documents, institutional ethos or as perceived by teachers, and with it remarks on the strength of professional identities.

Street-level bureaucracy allows exploring the job as understood and practiced by teachers and other educators. Questions worth asking focus on their ideals and what they think is expected from them, by the government, their organisation, their managers and colleagues. This may be linked to their experience of training and preparation for their professional role. 
A further step of using the street-level bureaucrat as an analytical tool is the relationship of teachers and rules. It includes questions about the knowledge of the regulative framework and about the extent of agency to influence it at the point of formulation. Then their practice can be examined using the typology of discretion within the rule, amongst rules, beyond rules or against rules (Barberis \& Buchowicz, 2015). Teachers' task discretion should then be explored as nestled in the various aspects of rule discretion.

Those working in education and teachers as street-level bureaucrats in particular struggle with the definition of the client, which is closely linked to value discretion. Obviously, children as pupils are clients. Yet, many choices are made by parents who then take the characteristics of clients. When the professional relationship of teachers is with this double client, questions of worthiness have a twist and may contribute to the understanding of inequality. What is the definitions of a worthy client parent and what is the definition of the worthy client pupil? How is this established in practice? What mechanisms are in place and used to teach good client behaviour and do teachers change their construction of the worthy (double) client over time? Do teachers move towards, away from or against (double) clients (Tummers et al., 2015) when the workload or other pressures increase?

Another advantage of the street-level bureaucrat perspective is that it lends itself to taking a fresh look at how education objectives and practices are linked to objectives and practices which seem to be situated outside the realm of education. The conceptualisation of children and childhood has to be considered in order to understand goals and the balance of education systems, the structure of the education system and the professional ideals of teachers. Therefore a focus on teachers' discretion extends inquiry beyond expected, preferred or even acknowledged outcomes and focuses on policies made in the classroom.

The exploration of applying the street-level lens to education also shows the benefits of ethnographic research. Some aspects of the decisions on the worthiness of pupils and the exclusion or inclusion of children from education at the micro level can only be accessed by classroom observations in combination with extensive knowledge of the socio-political and cultural context. It may be one approach that fills the gap of comparative (Foster, Addy \& Samoff, 2012) research based on classroom observations. Researchers will have to face common problems in comparative work, like ethnocentricity, language abilities and cultural variations as expressed in language and so is difficult to translate (Phillips \& Schweisfurth, 2015). The unit of analysis will be teachers and their practice in classrooms and schools. However, to identify all the policies on various levels and to capture the socio-cultural context will be more challenging and in this sense problematize the unit of analysis. And, as Hill (2009b) and Evans(2011) point out it also requires a better understanding and focus of the intersection of professional and management issues. As an analytical tool in comparative research on education policy the street-level bureaucrats' perspective has the potential to illuminate aspects difficult to grasp with other means. The unique links it makes between the macro and the micro offer bridges to research with a focus on each of these arenas. One of the attraction of findings from comparative street-level bureaucracy research is that it is can reveal that crude policy transfer is impossible and why that is so. 


\section{Acknowledgement}

The data used to inform this article was generated as part of the CATE project. Dr Peter Kelly, Plymouth University, UK lead the project. Co-researchers were Dr Hans Dorf, Aarhus University, Denmark and Dr Nick Pratt, Plymouth University, UK. 


\section{References}

Alexander, R. (2000) Culture and Pedagogy: International Comparisons in Primary Edcuation. Oxford: Blackwell.

Alexander, R. (2008) Essays on Pedagogy. London and New York: Routledge.

Autorengruppe Bildungsberichterstattung (2014) Bildung in Deutschland 2014: Ein indikatorengestützter Bericht mit einer Analyse zur Bildung von Menschen mit Behinderungen. Bielefeld: Bertelsmann.

Ball, S. J. (1990) Politics and Policy Making in Education. London: Routledge.

Ball, S. J. (2013) The Education Debate. 2nd edn. Bristol: Policy Press.

Ball, S. J., Maguire, M. \& Braun, A. (2012) How Schools Do Policy: Policy Enactments in Secondary Schools. London: Routledge.

Barberis, E. \& Buchowicz, I. (2015) 'Creating Accessibility to Education: The Role of School Staff's Discretionary Practices'. European Education, 47 (1), pp. 61-76.

Beck, J. (2008) 'Governmental professionalism: Re-professionalising or de-professionalising teachers in England?'. British Journal of Educational Studies, 56 (2), pp. 119-143.

Berkman, M. \& Plutzer, E. (2010) Evolution, Creationism, and the Battle to Control America's Classrooms. New York: Cambridge.

Bernstein, B. (1996) Peagogy, Symbolic Control and Identity: Theory, research, critique. London and New York: Talor \& Francis.

Braun, A., Maguire, M. \& Ball, S. J. (2010) 'Policy enactments in the UK secondary school: examining policy, practice and school positioning'. Journal of Education Policy, 25 (4), pp. 547-560.

Brodkin, E. Z. (2003) 'Street-level Research: Policy at the Front Lines', in Lennon, M.C. and Corbett, T. (eds.) Policy into Action: Implementation Research and Welfare Reform. Washington: The Urban Institute Press.

Brodkin, E. Z. (2011) 'Putting street-level organizations first: New directions for social policy and management research'. Journal for Public Administration Research and Theory, 21 (suppl 2), pp. i199-i201. 
Brodkin, E. Z. (2012) 'Reflections on street-level bureaucracy: Past, present and future: Book review'. Public Administration Review, 72 (6), pp. 940-949.

Croll, P. (ed.) (1996) Teachers, Pupils and Primary Schooling: Continuity and Change. London: Cassell.

Department for Education (DfE) (2011) Teachers' Standards: Statutory guidance for school leaders, school staff and governing bodies, July 2011 (introduction updated June 2013). London: DfE.

Dorch, E. L. (2009) 'The implications of policy pre-post test scores for street-level bureaucratic discretion'. Journal of Health \& Human Services Administration, 32 (2), pp. 141-165.

Dorf, H., Kelly, P., Hohmann, U. \& Pratt, N. (2013) 'Teacher Quality in a Political and Social Setting: Goals, Discourses, Constraints and Affordances - Implications for a Teacher Education Reform'. Journal of the International Society for Teacher Education, 17 (2), pp. 6-20.

Ellis, K. (2011) "Street-level Bureaucracy' Revisited: The Changing Face of Frontline Discretion in Adult Social Care in England'. Social Policy \& Administration, 45 (3), pp. 221-244.

Elmore, R. (1980) 'Backward mapping: Implementation researach and policy decisons'. Political Science Quarterly, 94 pp. 601-616.

European Commission, EACEA \& Eurydice (2016) 'Promoting citizenship and the common values of freedom, tolerance and non-discrimination: Paris Declaration of 17. March 2015'. [in Luxembourg: Office of the European Union. (Accessed:European Commission, EACEA \& Eurydice

Evans, T. (2011) 'Professionals, managers and discretion: Critiquing Street-level bureaucracy'. British Journal of Social Work, 41 pp. 368-386.

Evetts, J. (2009) 'The management of professionalism: a contemporary paradox', in Gewirtz, S., Mahony, P., Hextall, I. and Cribb, A. (eds.) Changing Teacher Professionalism: International Trends and Ways Forward. Abingdon and New York: Routledge.

Fend, H. (1981) Theorie der Schule. 2nd edn. München: Urban und Schwarzenberg.

Fend, H. (2008) Neue Theorie der Schule: Einführung in das Verstehen von Bildungssystemen. Wiesbaden: Verlag für Sozialwissenschaften.

Flechsig, K.-H. \& Haller, H.-D. (1975) Einführung in Didaktisches Handeln: Ein Lernbuch für Einzel- und Gruppenarbeit. Stuttgart: Klett.

Foster, J., Addy, N. A. \& Samoff, J. (2012) 'Crossing borders: Research in comparative and international education'. International Journal of Educational Development, 32 (6), pp. 711-732. 
Hendrick, H. (1994) Child Welfare: 1870-1989. London: Routledge.

Herzog, W. (2011) 'Schule und Schulklasse als soziale Systeme', in Becker, R. (ed.) Lehrbuch der Bildungssoziologie. 2. Auflage edn. Wiesbaden: Verlag für Sozialwissenschaften.

Hill, M. (2009a) Understanding Social Policy. 8th edn. Oxford: Blackwell.

Hill, M. (2009b) The Public Policy Process. 5th edn. Harlow: Pearson Education.

Hupe, P. (2013) 'Dimensions of discretion: Specifying the object of street-level bureaucracy research'. dms - der moderne staat, 6 (2), pp. 425-440.

Hupe, P., Hill, M. \& Nangia, M. (2014) 'Studying implementation beyond deficit analysis: The topdown view reconsidered'. Public Policy and Administration, 0 (0), pp. 1-19.

Kelly, P., Dorf, H., Pratt, N. \& Hohmann, U. (2014) 'Comparing teacher roles in Denmark and England'. Compare, 44 (4), pp. 566-586.

Kelly, P., Hohmann, U., Pratt, N. \& Dorf, H. (2013a) 'Teachers as mediators: an exploration of situated English teaching'. British Education Research Journal, 39 (4), pp. 609-634.

Kelly, P., Pratt, N., Dorf, H. \& Hohmann, U. (2013b) 'Comparing Pedagogy in Mathematics in Denmark and England'. European Educational Research Journal, 12 (4), pp. 553-567.

Klieme, E., Jude, N., Baumert, J. \& Prenzel, M. (2010) 'PISA 2000-2009: Bilanz der Veränderung im Schulsystem', in Klieme, E., Artelt, C., Hartig, J., Jude, N., Köller, O., Prenzel, M., Schneider, W. and Stanat, P. (eds.) PISA 2009. Münster: Waxmann, pp. 277-300.

Levin, B. (1998) 'An epidemic of education policy: what can we learn from each other?'. Comparative Education 34 pp. 131-141.

Lipsky, M. (1980) Street-Level Bureaucracy: Dilemmas of the individual in public services. New York: Russell Sage Foundation.

Lipsky, M. (2010) Street-Level Bureaucracy: Dilemmas of the individual in public services: 30 th anniversary expanded edition. New York: Russell Sage Foundation.

Lundström, U. \& Parding, K. (2011) 'Teachers' experiences with School Chooice: Clashing Logics in the Swedish Education System'. Education Researach International, open access article pp. 10 pages. 
Luxton, R. G. \& Last, G. (1998) 'Under-achievement and Pedagogy: Experimental Reforms in the Teaching of Mathematics using Continental Approaches in Schools in the London Borough of Barking and Dagenham'. Teaching Mathematics and its Applications, 17 (1), pp. 1-11.

Maynard-Moody, S. \& Musheno, M. (2003) Cops, Teachers, Counselors: Stories from the front lines of public services. Michigan: University of Michigan Press.

McCulloch, G., Helsby, G. \& Knight, P. (2000) The Politics of Professionalism: Teachers and the Curriculum. London: Continuum Publishing.

McLean, M. (1990) Britain and a Single Market Europe: Prospects for a Single School Curriculum, London: Kogan Page.

Meyer, H. (2004) Was ist guter Unterricht? Berlin: Cornelsen Scriptor.

Phillips, D. \& Ochs, K. (2004) 'Researching policy borrowing: Some methodological challenges in comparative education'. Britisch Educational Research Journal, 30 (6), pp. 773-784.

Phillips, D. \& Schweisfurth, M. (2015) Comparataive and International Education: An Introduction to Theory, Method, and Practice. 2nd edn. London: Bloomsbury.

Rønning, M. (2011) 'Who benefits from homework assignments?'. Economics of Education Review, 30 pp. 55-64.

Rowe, M. (2012) 'Going Back to the Street: Revisiting Lipsky's Street-level Bueraucracy'. Teaching Public Administration, 30 (1), pp. 10-18.

Schneider, T. (2005) 'Nachhilfe als Strategie zur Verwirklichung von Bildungszielen: Eine empirische Untersuchung des Sozio-oekonomischen Panels (SOEP)'. Zeitschrift für Pädagogik, 51 (3), pp. 363379.

Sharp, C., Keys, W. \& Benefield, P. (2001) Homework: A review of recent research. Slough: nfer. Available.

Singh, P., Thomas, S. \& Harris, J. (2013) 'Recontrextualising policy discourses: a Bernsteinian perspective on policy interpretation, translation, enactment'. Journal of Education Policy, 28 (4), pp. 465-480.

Spillane, J., Diamond, J. B., Burch, P., Hallett, T., Loyiso, J. \& Zoltners, J. (2002) 'Managing in the middle: School leaders and the enactment of accountability policy'. Educational Policy, 16 (5), pp. 731-762. 
Taylor, I. (2007) 'Discretion and control in education'. Educational Management Administration \& Leadership, 35 (4), pp. 555-572.

Taylor, I. \& Kelly, J. (2006) 'Professionals, discretion and public sector reform in the UK: re - visiting Lipsky'. International Journal of Public Sector Management, 19 (7), pp. 629-642.

Training and Development Agency (TDA) (2007) Professional Standards for Teachers: Why sit still in your career. London: TDA.

Tummers, L. \& Bekkers, V. (2014) 'Policy implementation, street-level bureaucracy and the importance of discretion'. Public Management Review, 16 (4), pp. 527-547.

Tummers, L. L. G., Bekkers, V., Vink, E. \& Musheno, M. (2015) 'Coping During Public Service Delivery: A Conceptualization and Systematic Review of the Literature'. Journal of Public Administration Research and Theory, 25 (4), pp. 1099-1126.

Verbeet, v., Markus \& Weinzierl, A. (2011) Ängstlichkeit regiert. Der Spiegel, 48,

Ward, S. \& Eden, C. (2009) Key Issues in Education Policy. London: SAGE.

Whitty, G. (2001) 'Teacher professionalism in new times', in Gleeson, D. and Husbands, C. (eds.) The Performing School: Managing, Teaching and Learning in a Performance Culture. London: Routledge Falmer. 